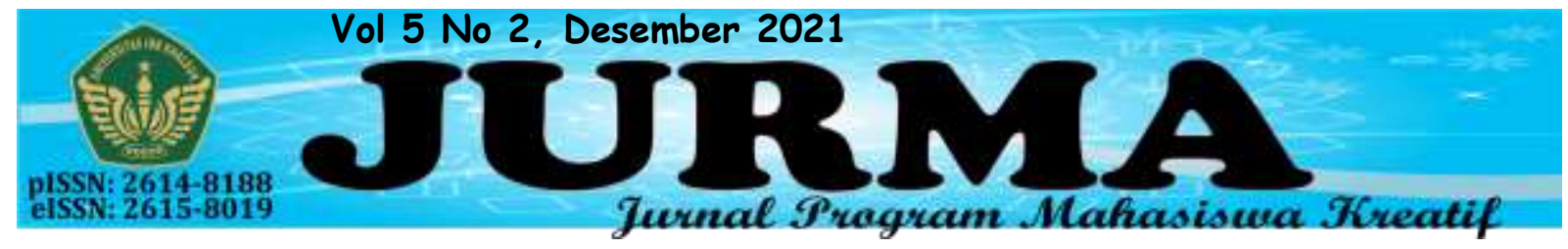

\title{
KEGIATAN KKNDR 174 UINSU DAN PENGARUHNYA TERHADAP MODERASI BERAGAMA DI DESA PASAR LARU
}

\author{
Azrul Sani ${ }^{1)}$, Ika Agustina ${ }^{2)}$, Yeni Emiliani ${ }^{3)}$, Sangkot Hayati ${ }^{4)}$, Agusman Damanik ${ }^{5)}$ \\ Universitas Islam Negeri Sumatera Utara Medan
}

kkndr174@gmail.com

\begin{abstract}
Abstrak
Tulisan ini merupakan hasil Kegiatan KKN DR salah satunya mengangkat tema moderasi beragama. KKN DR merupakan kegiatan pengabdian alternatif sebagai solusi menghadapi kondisi pandemi covid-19, tetapi dalam pelaksanaanya tidak mengurangi substansi dari KKN itu sendiri. Kegiatan KKN DR dilaksanakan agar dapat memberikan kontribusi konkret dalam membangun moderasi beragama di Desa Pasar Laru. Secara praksis sikap moderat dalam beragama diwujudkan dengan mengedepankan keseimbangan, pengendalian emosi agar tak berlebihan, serta sikap kehati-hatian dalam bersikap dalam beragama. Melihat keragaman budaya, keyakinan yang berbeda-beda dari tiap keluarga semarga yang ada dan pemahaman agama yang berbeda-beda. Apakah kegiatan KKN DR memberikan pengaruh terhadap moderasi beragama di Desa Pasar Laru?. lalu apa saja kegiatan yang dapat berpengaruh terhadap moderasi beragama tersebut. Menghadapi keragaman, maka diperlukan sikap moderasi, bentuk moderasi ini bisa berbeda antara satu tempat dengan tempat lainnya. Sikap moderasi berupa pengakuan atas keberadaan pihak lain, pemilikan sikap toleran, penghormatan atas perbedaan pendapat, dan tidak memaksakan kehendak.
\end{abstract}

Kata kunci : Moderasi Beragama, Kearifan Lokal

\section{PENDAHULUAN}

Slogan Moderasi Beragama yang digaungkan pemerintah terkadang hanya sebatas wacana. Akibatnya di tengah masyarakat masih muncul pemahaman

Universitas Islam Negeri Sumatera Utara (UINSU) dengan motto' UINSU Kita " hadir dengan tiga visinya diantaranya Moderasi Beragama, menunjukkan adanya keseriusan untuk merevitalisasi atau menguatkan kembali tentang pentingnya Penegakan Moderasi Beragama dengan berbagai persepsi dan pandangan.

Melalui kegiatan Kuliah kerja Nyata Mahasiswa Dari Rumah ( KKNDR) yang keagamaan yang bersifat eksklusif individual dengan kata lain bahwa kebenaran adalah pada pemahaman mereka sendiri, sementara pemahaman orang lain tidak benar.

sifatnya terukur, terutama pada kelompok. 174, penegakan Moderasi beragama akan menjadi hal yang penting khususnya bagi masyarakat yang ada di Pasar Laru kecamatan Tambangan kabupaten Mandailing Natal.

Pandemi virus corona 2019 (Covid19) telah membawa perubahan besar dalam perilaku politik, sosial ekonomi, pendidikan, dan berbagai aspek lain dalam 
kehidupan "normal" kita sehari-hari. Di sektor pendidikan, pola pembelajaran dengan tatap muka langsung di kelas, banyak yang terhenti karena adanya anjuran physical distancing sebagai salah satu upaya untuk mencegah penularan Covid-19. Demikian juga dengan KKN (Kuliah Kerja Nyata), yang semestinya memberikan ruang yang cukup bagi mahasiswa untuk berinteraksi secara langsung dan belajar bersama dengan masyarakat, mengalami kendala terkait pelaksanaannya. KKN merupakan bagian dari perkuliahan yang memiliki peran strategis dalam mengintegrasikan ranah pengabdian dengan pendidikan dan penelitian sehingga kepedulian dan kepekaan sosial (civic responsibility) mahasiswa tumbuh dan berkembang. Oleh karena itu, diperlukan alternatif-alternatif model pelaksanaan KKN selama masa pandemic Covid-19 untuk mendorong lahirnya generasi yang bertanggung jawab dan tanggap terhadap kondisi kekinian masyarakat. Di samping itu, faktor masa studi mahasiswa yang diperkirakan akan semakin lama jika KKN ditiadakan juga menjadi salah satu pertimbangan pelaksanaan KKN Tanggap Covid-19.

Merujuk pada pengalaman pelaksanaan KKN sebelumnya, KKN di UIN Sumatera Utara biasanya dilaksanakan di desa-desa yang tersebar di beberapa Kabupaten di Sumatera Utara, pada bulan Juli sampai dengan Agustus. Namun dengan kondisi saat ini, dimana mahasiswa melaksanakan semua kegiatan perkuliahan dari rumah masing-masing, maka perlu adaptasi penyelenggaraan KKN yang rencananya akan dilaksanakan antara bulan Juli sampai dengan Agustus 2021. Pola pelaksanaan KKN tanggap Covid-19 akan diarahkan pada pencegahan penularan Covid-19 dan penguatan kapasitas masyarakat dalam menanggulangi dampak Covid-19 dengan model KKN-DR (Kuliah Kerja Nyata dari Rumah), KKN-DS (Kuliah Kerja Nyata Kerja Sosial), dan KKN berbasis riset.

\section{METODE PENELITIAN}

\subsection{Teknik Penelitian}

Penelitian ini menggunakan deskriptif kualitatif dengan teknik wawancara, terjun ke lapangan mengumpulkan data dan melakukan interaksi langsung dengan (objek) masyarakat. dimana rumusan masalah yang akan memandu penelitian untuk mengeksplorasi atau memotret situasi sosial yang akan diteliti secara menyeluruh, luas dan mendalam. Data yang ada pada peneletian deskriptif kualitatif ini bersifat induktif dan hasil penelitian kualitatif lebih menekankan makna dari pada generalisasi. ${ }^{1}$

\subsection{Pengumpulan Data}

Penelitian ini diperoleh dengan data yang benar dan dapat dipertanggung jawabkan, maka peneliti menggunakan beberapa metode. Adapun metode yang digunakan wawancara dan interaksi dengan masyarakat.

\subsection{Analisis Data}

Analisis data adalah upaya yang dilakukan oleh penulis untuk mencari dan menata secara sistematis catatan hasil wawancara, observasi yang telah dilakukan untuk meningkatkan pemahaman peneliti tentang kasus yang diteliti. Penulis melakukan analisis data dengan cara sebagai berikut yaitu Analisis data yang didapatkan dari metode wawancara dan terjun kelapangan.

\section{HASIL dan PEMBAHASAN}

\subsection{UINSU dan KKNDR Terukur}

Universitas Islam Negeri Sumatera Utara (UIN SU) adalah perguruan tinggi Islam negeri yang berada di Medan, Sumatra Utara. UIN Sumatra Utara yang didirikan pada tahun 1973 di Medan, dilatar belakangi dan didukung oleh beberapa faktor pertimbangan

1 Sugiyono. 2016. Metode Penelitian Kuantitatif, Kualitatif dan $R \& D$. Bandung: Alfabeta 
objektif. Pertama, Perguruan Tinggi Islam yang berstatus Negeri pada saat itu belum ada di Provinsi Sumatra Utara, walaupun Perguruan Tinggi Agama Islam Swasta memang sudah ada. Kedua, pertumbuhan pesantren, madrasah dan perguruanperguruan agama yang sederajat dengan SLTA di daerah Sumatra Utara tumbuh dan berkembang dengan pesatnya, yang sudah tentu memerlukan adanya pendidikan lanjutan yang sesuai, yakni adanya Perguruan Tinggi Agama Islam yang berstatus Negeri. ${ }^{2}$

UINSU memiliki tujuan Menghasilkan sarjana (lulusan) yang karakter ulul al-bab serta memiliki keunggulan kompetitif dalam persaingan global, Menyiapkan peserta didik agar menjadi warga negara dan anggota masyarakat yang memiliki kemampuan akademik, profesi, dan atau vokasi yang unggul serta dapat mengembangkan kajian keislaman, sains dan teknologi, serta seni yang berbasis transdisipliner sesuai dengan nilai - nilai Islam, Menyebarluaskan kajian Islam, sains, teknologi dan seni, berbasis transdisiplinerberlandaskan nilai-nilai Islamuntuk membangun peradaban di Sumatera Utara, Indonesia dan Dunia. ${ }^{3}$

Saat ini, Mahasiswa UIN Sumatera Utara sedang melaksanakan KKN DR terukur yang sistem pengelompokan mahasiswa berdasarkan regional tempat tinggal mereka. Dikarenakan kondisi saat ini yang masih dalam keadaan pandemi covid-19, para UINSU memiliki tujuan Menghasilkan sarjana (lulusan) yang karakter ulul al-bab serta memiliki keunggulan kompetitif dalam persaingan global, Menyiapkan peserta didik agar menjadi warga negara dan anggota masyarakat yang memiliki kemampuan

https://id.wikipedia.org/wiki/Universitas_Islam_Negeri_ $\underline{\text { Sumatera_Utara }}$

https://www.tribunnewswiki.com/2020/05/13/universitasislam-negeri-sumatera-utara-uinsu akademik, profesi, dan atau vokasi yang unggul serta dapat mengembangkan kajian keislaman, sains dan teknologi, serta seni yang berbasis transdisipliner sesuai dengan nilai - nilai Islam, Menyebarluaskan kajian Islam, sains, teknologi dan seni, berbasis transdisiplinerberlandaskan nilai-nilai Islamuntuk membangun peradaban di Sumatera Utara, Indonesia dan Dunia. ${ }^{4}$

Mahasiswa tidak bisa menjalankan KKN sebagaimana biasanya. Oleh karena itu, KKN yang di adakan pada tahun ini ialah KKN DR Terukur.

Menjalankan pengabdian masyarakat sebagai salah satu persyaratan meraih gelar sarjana di Universitas Islam Negeri Sumatera Utara. Pengabdian masyarakat dilakukan mahasiswa didalam sebuah desa yang dilaksanakan dalam waktu 1 bulan.

Mahasiswa KKN DR 174 UINSU mengambil sebuah tempat disebuah Desa Pasar Laru Kecamatan Tambangan Kabupaten Mandailing Natal. KKN DR UINSU tahun ini mengambil sebuah visi misi yaitu, "Kembali Kedesa, Benahi Desa, Berbasis Moderasi Beragama dan Wahdatul Ulum". Ada pun lima tema yang di usung pada KKN tahun ini yaitu, Sosial Kemasyarakatan, Keagamaan dan Keislaman. Kesehatan Masyarakat, Sains dan Teknologi, Moderasi Beragama dan Kerukunan Umat Beragama.

\subsection{Moderasi Beragama Di Pasar Laru}

Indonesia adalah negara kepulauan yang memiliki keragaman budaya, ras, suku bangsa, kepercayaan, agama, dan bahasa. Keanekaragaman yang dimiliki bangsa Indonesia merupakan kekayaan dan keindahan wilayah negara Indonesia. Keberagaman adalah suatu kondisi dalam masyarakat yang terdapat banyak perbedaan dalam berbagai bidang. Perbedaan tersebut dalam hal suku bangsa,

https://www.tribunnewswiki.com/2020/05/13/universitasislam-negeri-sumatera-utara-uinsu 
ras, agama, keyakinan, ideologi politik, sosial-budaya, dan ekonomi. ${ }^{5}$

Indonesia memiliki perbedaan yang sangat banyak, namun dari setiap perbedaan pasti dibalut dengan rasa kasih sayang dan saling menghargai perbedaan dari masing-masing Insan. Indonesia menjadi negara paling kaya disebabkan keanekaragaman yang dimiliki setiap masyarakatnya. Islam hadir kedepan menjadi agama yang menjunjung tinggi perbedaan, sebagaimana Firman Allah Q.S. Hujarat ayat 13:

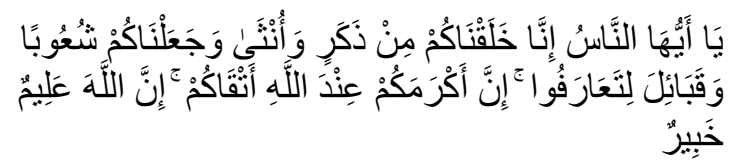

Artinya :

" Hai manusia, sesungguhnya Kami laki-menciptakan kamu dari seorang laki dan seorang perempuan dan menjadikan suku -bangsa dan bersuku-kamu berbangsa .mengenal-supaya kamu saling kenal Sesungguhnya orang yang paling mulia diantara kamu disisi Allah ialah orang yang paling takwa diantara kamu. Sesungguhnya Allah Maha Mengetahui lagi Maha Mengenal“.

Dalam ayat ini dijelaskan bahwa Agama Islam sangat menjunjung tinggi perbedaan yang dimiliki setiap orang. Dalam ayat ini ada kalimat perintah kepada setiap Muslim dimana orang yang paling mulia diantara setiap Insan ialah orang yang bertakwa dan hamba yang bertakwa kepada Tuhan-NYA (Allah) pasti menghargai perbedaan yang dimiliki setiap orang.

Moderasi beragama harus dapat dipahami sebagai sikap beragama yang seimbang antara pengamalan agama sendiri (eksklusif) dan penghormatan kepada praktik beragama orang lain yang berbeda keyakinan (inklusif).

https://www.tribunnews.com/pendidikan/2021/08/02/keb eragaman-mas yarakat-indonesia-dan-faktor-penyebabnya Pada Tanggal 17 Agustus 2021.
Keseimbangan atau jalan tengah dalam praktik beragama ini niscaya akan menghindarkan kita dari sikap ekstrem berlebihan, fanatik dan sikap revolusioner dalam beragama. Seperti telah diisyaratkan sebelumnya, moderasi beragama merupakan solusi atas hadirnya dua kutub ekstrem dalam beragama, kutub ultrakonservatif atau ekstrem kanan di satu sisi, dan liberal atau ekstrem kiri di sisi lain. Moderasi beragama sesungguhnya merupakan kunci terciptanya toleransi dan kerukunan, baik di tingkat lokal, nasional, maupun global. Pilihan pada moderasi dengan menolak ekstremisme dan liberalisme dalam beragama adalah kunci keseimbangan, demi terpeliharanya peradaban dan terciptanya perdamaian. Dengan cara inilah masing-masing umat beragama dapat memperlakukan orang lain secara terhormat, menerima perbedaan, serta hidup bersama dalam damai dan harmoni. Dalam masyarakat multikultural seperti Indonesia, moderasi beragama bisa jadi bukan pilihan, melainkan keharusan. ${ }^{6}$

Istilah moderasi diambil dari bahasa arabik dari akar kata yang sama yaitu "WASATHA" yang artinya tengah atau moderat. Dalam Islam berarti menyatakan watak Islam adalah moderat dalam hal bertindak dan moderat dalam segala urusan baik, tindakan, ucapan, atau pikiran. ${ }^{7}$ Selain dari istilah ini, masih banyak pendapat-pendapat para ulama dan para pakar pendidikan yang menjelaskan arti Moderasi Beragama.

Anis Malik Thoha mengatakan bahwa muslim moderat adalah seorang muslim yang memenuhi islamik prinsiple wassatiyah (prinsip moderasi dalam islam) antara lain tidak ekstrim kanan maupun kiri. Hal ini berarti bahwa muslim harus

6 Tim Penyusun Kementerian Agama RI, MODERASI BERAGAMA, (Jakarta: Kementerian Agama RI, 2019) hal 18.

7 Widodo, Priyantoro, and Karnawati Karnawati. "Moderasi Agama dan Pemahaman Radikalisme di Indonesia." PASCA: Jurnal Teologi dan Pendidikan Agama Kristen 15.2 (2019): 10. 
mampu menjaga dirinya untuk tidak menggunakan kekerasan, melainkan membawa kedamaian dan rahmat untuk semua alam; juga memahami bahwa islam memiliki hukum yang bersifat tetap dan ada yang bisa berubah atau diijtihadkan sesuai perkembangan jaman; tidak menggunakan pemaksaan; tidak mengkompromikan hal-hal dasar dalam agama hal ini untuk menjaga kesucian beragama; mengkompromikan hal-hal yang bersifat fundamental dalam beragama yaitu hidup rukun berdampingan dengan siapapun. ${ }^{8}$

Kemudian, dengan nada yang sama mengenai pengertian dari al-wasathiyah yang dapat bisa juga dikenal dengan attawadzun menurut Yusuf Qardhawi yaitu, suatu upaya menjaga keseimbangan antara dua sisi/ujung/pinggir yang berlawanan atau bertolak belakang, agar jangan sampai yang satu mendominasi dan menegaskan yang lain. Bersikap seimbang dalam menyikapinya yaitu dengan memberi porsi yang adil dan proporsional kepada masingmasing pihak tampa berlebihan, baik terlalu banyak maupun terlalu sedikit. ${ }^{9}$

Sejalan dengan berbagai pengertian diatas, secara terminologi Moderasi agama yaitu sebuah pandangan atau sikap yang selalu berusaha mengambil posisi tengah dari dua sikap yang bersebrangan dan berlebihan sehingga salah satu dari kedua sikap yang dimaksud tidak mendominasi dalam pikiran, dan sikap sesorang. Dengan kata lain, modertat adalah memberi setiap nilai yang bersebrangan tidak lebih dari hak yang semestinya. ${ }^{10}$

Sejalan dengan penjelasan diatas, paham Islam moderat merupakan ideologi

${ }^{8}$ Ibid, hal 10.

9 Zamimah, Iffati. "Moderatisme islam dalam konteks keindonesiaan." Jurnal Al-Fanar 1.1 (2018): 7590 .

${ }^{10}$ Al-Fikra, "Radikalisme Islam vs Moderasi Islam Upaya Membangun Wajah Islam Indonesia Yang Damai”, Jurnal Ilmiah Keislaman, Vol. 17, No. 1, (Juni, 2018), h.48 keagamaan yang sangat relevan dalam segala aspek konteks keberagaman, baik segi agama, segi adat istiadat, maupun dari segi suku dan bangsa itu sendiri.Tidak dapat dipunkiri lagi bahwa, beragamnya pemahaman tentang keagamaan merupakan suatu bukti nyata adanya sejarah dalam Islam. adanya keragaman paham tersebut, salah satunya disebabkan oleh adanya dialektika antara teks dan realitas itu sendiri, dan cara pandang terhadap posisi akal dan wahyu dalam menyelesaikan suatu permasalahan. ${ }^{11}$

Dari berbagai pendapat para ahli diatas, dapat disimpulkan kembali bahwa moderasi beragama adalah cara seseorang memeluk ajaran yang diyakininya dan berusaha menjadi Islam yang moderat, yaitu beragama Islam yang tidak terlalu ekstrim. Beragama yang ekstrim merupakan moderat yang salah dalam masyarakat, sebab dapat menimbulkan perpecahan dan perselisihan di masyarakat.

Keragaman budaya merupakan peristiwa alami karena bertemunya berbagai perbedaan budaya di suatu tempat, setiap individu dan kelompok suku bertemu dengan membawa perilaku budaya masing-masing, memiliki cara yang khas dalam hidupnya. ${ }^{12}$ Desa Pasar Laru merupakan desa kecil yang terletak di Kabupaten Mandailing Natal, Kecamatan Tambangan, Desa Pasar Laru. Desa Pasar Laru memiliki keragaman budaya yang sangat kental dan kuat, diamana dapat dirasakan sendiri mengenai keragaman yang ada di Desa Pasar Laru.

Desa Pasar Laru memiliki tiga keluarga besar, sering dikatakan dengan keluarga semarga, diantaranya: Keluarga Lubis Raja, Keluarga Lubis Angin Barat dan Keluarga Lubis Laru Dolok. Dari

${ }^{11}$ Edy Sutrisno, “Aktualisasi Moderasi Beregama di Lembaga Pendidikan",Jurnal Bimas Islam,Vol.12 No.1, (Desember, 2019), h.328-329.

12 Akhmadi, Agus. "Moderasi Beragama dalam Keragaman Indonesia." Inovasi-Jurnal Diklat Keagamaan 13.2 (2019): 47. 
keluarga semarga ini, kita dapat melihat sebuah keragaman budaya dan keyakinan yang berbeda-beda dari tiap keluarga semarga yang ada. Toleransi dan sikap saling menghargai dari tiap keluarga semarga dengan keluarga semarga yang lain sangat kuat di Desa Pasar Laru, hal tersebut tergambarkan ketika ada musibah atau suatu kemalangan, pasti ketiga keluarga semarga ini ikut turut hadir dan membantu Pardhu Kifayahnya.

Dari cerita di atas terdapat pelajaran penting dalam menjadi seorang Islam yang moderat, dimana masyarakat Desa Pasar Laru yang memiliki keragaman yang berbeda-beda masih tetap bersatu dalam keyakinan beragama yang ada. Keragaman yang dirasakan di Desa Pasar Laru tidak menjadi penghambat untuk terus mencari keridoan Allah, sebab dengan adanya perbedaan keragaman dapat memberikan pelajaran kepada masayarakat agar selalu menghargai perbedaan orang lain.

\subsection{Pengaruh Kegiatan KKN DR 174 terhadap Moderasi beragama di Pasar Laru}

Pasar Laru merupakan salah satu desa yang ada di kecamatan Tambangan, kabupaten Mandailing Natal. Semboyan Kabupaten Mandailing Natal adalah "Bumi gordang sambilan, Negeri beradat taat beribadat". Hal ini ditunjukan dengan Desa Pasar Laru kecamatan Tambangan, yaitu salah satu desa yang kaya akan adat dan masyarakatnya yang memahami dan mengamalkan ajaran agama dengan tidak ekstrem. Ekstremisme, radikalisme, ujaran kebencian (hate speech), hingga retaknya hubungan antarumat beragama. Masyarakat di desa ini memiliki Keragaman budaya, yaitu peristiwa alami karena bertemunya berbagai perbedaan budaya di suatu tempat, setiap individu dan kelompok suku bertemu dengan membawa perilaku budaya masing-masing, memiliki cara yang khas dalam hidupnya. Tugas untuk menyadarkan masyarakat tentang multikultural ini tidaklah mudah, bahkan membangun kesadaran kalangan masyarakat bahwa kebhinekaan adalah sebuah keniscayaan sejarah. Menanamkan sikap yang adil dalam menyikapi kebinekaan adalah perkara yang lebih sulit, karena, penyikapan terhadap kebhinekaan kerap berimpitan dengan berbagai kepentingan sosial, ekonomi, dan politik. Banyak program yang berkaitan dengan moderasi beragama yang dilakukan oleh kelompok KKN di Desa Pasar Laru seperti melakukan kegiatan acara tausiyah (ceramah keagamaan) baik antar pemuda dan pemudi setempat dan mengajak para ibu-ibu dan bapak-bapak setempat, agar masyarakat di desa tersebut semakin memiliki banyak ilmu tentang agama dan semakin terciptanya kerukunan antar masyarakat. Kegiatan-kegiatan ini umumnya didukung oleh pemerintah setempat melalui anggaran-anggaran pembangunan yang ada.

Kelompok KKN juga sering melakukan perkumpulan dengan pemuda pemudi di Desa Pasar Laru, guna untuk menjalin hubungan yang baik dengan masyarakat setempat. Masyarakat Desa Pasar Laru memberikan perlakuan yang baik untuk dijadikan sebagai contoh dengan menerapkan sikap toleransi dengan saling menghargai dan menghormati antar kelompok maupun individu. Dengan demikian moderasi beragama merupakan sebuah jalan tengah di tengah keberagaman agama di Indonesia. Moderasi merupakan budaya Nusantara yang berjalan seiring, dan tidak saling menegasikan antara agama dan kearifan lokal (local wisdom). Tidak saling mempertentangkan namun mencari penyelesaian dengan toleran.

Pelaksanaan KKN DR di Desa Pasar Laru salah satunya ingin mewujudkan moderasi beragama melalui kegiatan KKN DR dan bagaimana pengaruhnya terhadap moderasi beragama di Desa Pasar Laru. Setelah sekian rangkaian program telah dilaksanakan dalam kurun waktu 30 hari. Terdapat banyak sekali pengaruh dari kegiatan KKN DR kelompok 174. 
Moderat berarti memahami dan mengamalkan ajaran agama dengan tidak ekstrem, baik ekstrem kanan maupun ekstrem kiri. Ekstremisme, radikalisme, ujaran kebencian hingga retaknya hubungan antar umat beragama, merupakan problem yang dihadapi oleh bangsa Indonesia saat ini. ${ }^{13}$

Kegiatan KKN DR merupakan salah satu kegiatan mempengaruhi moderasi beragama di Desa Pasar Laru, seperti kegiatan yang disebutkan sebelumnya. Kegiatan ini diharapkan dapat menyampaikan pesan-pesan agama maupun pesan-pesan baik lannya. Kegiatan KKN DR dalam masyarakat sangat penting karena sebagian masyarakat masih memandang pentingnya sosok ideal sebagai figur atau patron dalam kehidupan masyarakat, oleh karena itu mahasiswa memiliki potensi untuk didudukkan sebagai figur di masyarakat.

Eksistensi KKN DR dapat dilihat sebagai agen yang dapat membentuk struktur dalam masyarakat. Aktifitas para mahasiswa melalui praktik atau tindakan selama KKN akan menjadi contoh atau sebagai aktor. Para mahasiswa sebagai agen akan mengembangkan kebiasaan sehari-hari yang tak hanya memberikan perasaan aman, tetapi juga memungkinkan mereka menghadapi kehidupan sosial mereka secara efisien. Untuk menumbuhkan motivasi dan melakukan tindakan-tindakan membangun kesadaran dan sikap moderasi beragama tersebut, Kegiatan KKN DR diharapkan berfungsi sebagai :

1. informatif dan edukatif; Memposisikan sebagai juru dakwah yang berkewajiban mendakwahkan ajaran agamanya, menyampaikan

13 Mohammad Nasikhuddin, dkk. Sosialisasi Pencegahan Penyebaran Covid-19 dan Urgensi Pendidikan Moderasi Beragama. Journal of Dedication Based on Local Wisdom, Vol 1 No 1. ( Jombang Jember : Institut Agama Islam Negeri Jember, 2021 ), $h \operatorname{lm} 2$. kebenaran agama dan mendidik masyarakat sesuai ajaran agama.

2. Fungsi Konsultatif : Menyediakan dirinya untuk turut memikirkan dan memecah-kan persoalan-persoalan yang dihadapi masyarakat, baik secara pribadi, keluarga maupun sebagai masyarakat umum.

3. Fungsi administratif: Memiliki tugas untuk merencanakan, melaporkan dan mengevaluasi pelaksanaan penyuluhan dan bimbingan yang telah dilakukannya (Amirulloh, 2016). ${ }^{14}$

Dari berbagai kegiatan KKN DR mengenai moderasi beragama yang telah dilakukan di Desa Pasar Laru, dengan demikian munculnya kesadaran masyarakat bahwa dalam keberagaman terdapat beragam keragaman seperti perbedaan dan keragaman faham agama. Dalam mengejawantahkan keagamaannya, masing masing perlu dihormati. Dengan keyakinan itulah akan mengantarkan kepada sikap keterbukaan, toleran, dan fleksibel dalam bertingkah.

Adapun pengaruh dari kegiatan $\mathrm{KKN}$ DR terhadap moderasi beragama di pasar laru, ialah :

1. Terjadinya interaksi yang tinggi antara masyarakat dan mahasiswa dalam pelaksanaan kegiatan KKN DR

2. Masyarakat Desa Pasar Laru menunjukkan sikap berpartisipasi dalam kegiatan KKN DR, seperti kegiatan acara tausiyah (ceramah keagamaan) baik antar pemuda dan pemudi setempat dan mengajak para ibu-ibu dan bapak-bapak setempat.

3. Kegiatan pembelajaran di MDA moderasi beragama menggunakan media gambar, video dan cerita menarik sehingga

14 Agus Akhmadi. Moderasi Beragama Dalam Keagamaan Indonesia Religious Moderation In Indonesia's Diversity. “ Jurnal Diklat Keagamaan Vol. 13 No. 2, ( Februari-Maret ) 2019, hlm, 50-51. 
anak-anak menjadi lebih paham dengan ilustrasi yang disampaikan dan anak-anak supaya paham apa itu toleran dan tidak mencela agama lain dengan alasan apapun.

4. Kegiatan KKN DR menambah sikap Toleransi dan sikap saling menghargai dari tiap keluarga semarga dengan keluarga semarga yang lain di Desa Pasar Laru,

5. Kajian oleh tokoh agama mengenai moderasi beragama membawa pemahaman bagaimana berhubungan kepada masyarakat atau hablum minannas.

6. Munculnya kesadaran masyarakat bahwa dalam keberagaman terdapat beragam keragaman seperti perbedaan dan faham agama, masing masing perlu dihormati.

\section{PENUTUP}

Kegiatan pengabdian KKN DR ini dilaksanakan dari rumah terukur dan berkelompok yang di tentukan oleh LP2M. Kegiatan KKN DR dilakukan untuk tetap melaksanakan KKN meskipun di masa pandemi. Dengan KKN DR ini juga mampu memutus rantai penyebaran covid19 di masyarakat. Kegiatan yang dilakukan berupa sosialisasi mengenai covid-19, belajar mengajar di MDA tugas pengabdian ini memberikan wadah dengan cara membantu mengajari anak-anak sekolah untuk menyelesaikan tugasnya, mengajar ngaji, dan lain sebagainya, acara tausiyah (ceramah keagamaan) baik antar pemuda dan pemudi setempat dan mengajak para ibu-ibu dan bapak-bapak setempat, dan webinar keagamaan yang bertema moderasi beragama, supaya mampu menambah pengetahuan mengenai moderasi beragama.

Moderasi beragama dapat dipahami sebagai sikap beragama yang seimbang antara pengamalan agama sendiri (eksklusif) dan penghormatan kepada praktik beragama orang lain yang berbeda keyakinan (inklusif). Keseimbangan atau jalan tengah dalam praktik beragama ini niscaya akan menghindarkan kita dari sikap ekstrem berlebihan, fanatik dan sikap revolusioner dalam beragama.

Di Desa Pasar Laru sendiri moderasi beragama sudah tergambarkan dari keragaman budaya dan keyakinan yang berbeda-beda dari tiap keluarga semarga yang ada. Toleransi dan sikap saling menghargai dari tiap keluarga semarga dengan keluarga semarga yang lain sangat kuat di Desa Pasar Laru.

Banyak kegiatan-kegiatan yang dilakukan oleh kelompok KKN DR 174 di Desa Pasar Laru dan memberi pengaruh yang baik terhadap moderasi beragama di desa tersebut. Sehingga sikap toleransi, saling menghargai, keragaman faham agama dan keragaman budaya keyakinan yang berbeda-beda dari tiap keluarga maupun semarga masing masing saling meghormati dan mengantarkan masyarakat di Desa Pasar Laru kepada sikap keterbukaan, toleran, dan fleksibel dalam bertingkah.

\section{DAFTAR PUSTAKA}

Akhmadi,Agus. (2019). Moderasi Beragama dalam Keragaman Indonesia. Inovasi jurnal dikat keagamaan.13(2).45-55.

Al-Fikra, (2018). " Radikalisme Islam vs Moderasi Islam Upaya Membangun Wajah Islam Indonesia Yang Damai ", Jurnal Ilmiah Keislaman, Vol. 17, No. 1, Juni.

Haryani,Elma. (2020). Pendidikan Moderasi Beragama untuk Generasi Milenial: Studi kasus Lone wolf pada anak di Medan. Jurnal penelitian pendidikan agama dan keagamaan. 18(2).145-158.

https://id.wikipedia.org/wiki/Universitas_I slam_Negeri_Sumatera_Utara

https://www.tribunnewswiki.com/2020/05/ 13/universitas-islam-negeri- 
sumatera-utara-uinsu

https://www.tribunnews.com/pendidi kan/2021/08/02/keberagaman-

masyarakat-indonesia-dan-faktorpenyebabnya

Iffati, Zamimah. (2018). Moderatisme islam dalam konteks keindonesiaan. Jurnal Al-Fanar. 1.1. 75-90.

Nasikhuddin, Muhammad, dkk. (2021). Sosialisasi Pencegahan Penyebaran Covid-19 dan Urgensi Pendidikan Moderasi Beragama. Journal of Dedication Based on Local
Wisdom, Vol 1 No 1. Jombang Jember : Institut Agama Islam Negeri Jember.

Sugiyono. (2016). Metode Penelitian Kuantitatif, Kualitatif dan $R \& D$. Bandung: Alfabeta

Sutrisno, Edy. (2019). Aktualisasi Moderasi Beregama di Lembaga Pendidikan, Jurnal Bimas Islam,Vol.12 No.1, Desember.

Tim Penyusun Kementerian Agama RI. (2019). Moderasi Beragama, Jakarta: Kementerian Agama RI. 